\title{
PERTANGGUNGJAWABAN PIDANA NOTARIS DALAM \\ PEMBUATAN AKTA YANG DIDASARKAN PADA KETERANGAN \\ PALSU DIHUBUNGKAN DENGAN UNDANG-UNDANG \\ NOMOR 30 TAHUN 2004 TENTANG JABATAN NOTARIS \\ JO UNDANG-UNDANG NOMOR 2 TAHUN 2014 DAN KUHP
}

\author{
Hilda Sophia Wiradiredja \\ Notaris dan PPAT di Kota Bandung \\ E-mail: sophiahilda@yahoo.com
}

\begin{abstract}
A notary occasionally receives false information from some parties, and then it becomes the basis of the making of authentic Notarial Deed. Notary criminal liability on the Notarial Deed based on false information should be analyzed and examined as well as its legal impacts.

Based on the result of this research, it can be identified that a notary cannot be asked for his or her criminal liability related to the making of Notarial Deed based on false information from certain parties, and it cannot fulfill the formulation of counterfeiting criminal act in article 266 paragraph (1) jo. article 55 paragraph (1) of Criminal Code. A notary can be asked for his or her criminal liability related to his or her Notarial Deed he or she made based on what he or she has seen, witnessed, or experienced in committing a criminal act on purpose, or negligence; a notary makes a false Notarial Deed and he or she inflicts other parties. Referring to a criminal liability, a notary should fulfill the following elements; a criminal act, ability to be responsible for, committing an act on purpose or absence, and there is no reason for apology. A notary Notarial Deed based on false information does not automatically make the document itself invalid. The party who is inflicted by this document can propose a civil action to the Court of Justice in order to cancel the document. A notary criminal liability should be regulated in the next Notary Authority Act (UUJN).
\end{abstract}

Keywords: criminal liability; notary; the making of Notarial Deed.

\section{Abstrak}

Seorang notaris terkadang tanpa diketahuinya ada keterangan palsu yang disampaikan para pihak, yang kemudian menjadi dasar pembuatan akta autentik. Perlu dikaji dan dianalisis pertanggungjawaban pidana notaris atas akta yang dibuat berdasarkan keterangan palsu serta mengkaji dan menganalisis akibat hukum yang timbul terhadap akta notaris yang didasarkan pada keterangan palsu.

Berdasarkan hasil penelitian diketahui bahwa notaris tidak dapat dimintai pertanggungjawaban pidana terkait pembuatan akta yang didasarkan pada keterangan palsu para pihak, dan tidak dapat memenuhi rumusan unsur tindak pidana pemalsuan dalam Pasal 266 ayat (1) juncto Pasal 55 ayat (1) KUHP. Notaris dapat dimintai pertanggungjawaban pidana terhadap akta yang dibuat olehnya berdasarkan apa yang dilihat, disaksikan, dan dialaminya dalam suatu perbuatan hukum jika secara sengaja atau lalai, notaris membuat akta palsu sehingga merugikan pihak lain. Pertanggungjawaban 
secara pidana, seorang notaris harus memenuhi unsur-unsur: melakukan tindak pidana; memiliki kemampuan untuk bertanggung jawab; dengan kesengajaan atau kealpaan; dan tidak ada alasan pemaaf. Terhadap akta notaris yang dibuat berdasarkan keterangan palsu tidak dengan sendirinya mengakibatkan akta tersebut batal demi hukum. Para pihak yang dirugikan dengan keberadaan akta seperti itu harus mengajukan gugatan perdata ke pengadilan untuk membatalkan akta tersebut. Pertanggungjawaban pidana notaris perlu diatur dalam UUJN yang akan datang.

Kata Kunci: Pertanggungjawaban Pidana, Notaris, Pembuatan Akta.

\section{A. PENDAHULUAN}

Indonesia adalah negara hukum. Hal ini dinyatakan secara tegas dalam Pasal 1 ayat (3) Undang-Undang Dasar 1945 (UUD 1945). Negara hukum adalah negara yang menjalankan sistem pemerintahannya berdasarkan atas hukum (rechtstaat), tidak berdasarkan atas kekuasaan (machstaat). Negara tidak maha kuasa, negara tidak dapat bertindak sewenang-wenang. ${ }^{1}$ Kekuasaan (negara) tanpa hukum tidak memiliki kewibawaan, sedangkan hukum tanpa (dukungan) sanksi, sulit untuk ditegakkan. Dalam hubungan tersebut, hukum melegitimasi negara, sedangkan negara mempositifkan (menciptakan, menegaskan, dan memberlakukan) dan menegakkan hukum. Jadi, yang menjadi ciri khas negara hukum adalah hubungan antara negara dan hukum. Keduanya saling terkait dan saling mengisi.

Lembaga notaris adalah lembaga kemasyarakatan yang dikenal sebagai "notariat", yang timbul dari kebutuhan masyarakat yang menghendaki adanya alat bukti mengenai hubungan hukum keperdataan yang ada dan/atau terjadi di antara mereka. Lembaga notaris dengan para pengabdinya ditugaskan oleh kekuasaan umum (openbaar gezag), untuk di mana dan apabila undangundang mengharuskan demikian atau dikehendaki oleh masyarakat, membuat alat bukti tertulis yang mempunyai

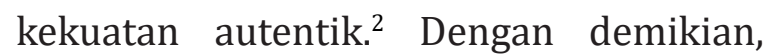
jabatan notaris lahir karena kebutuhan masyarakat, bukan jabatan yang sengaja diciptakan dan kemudian baru disosialisasikan kepada masyarakat umum.

Sejarah lahirnya notaris diawali dengan lahirnya profesi scribe pada masa Romawi Kuno (abad ke-2 dan ke-3 Masehi). Scribe adalah seorang terpelajar yang bertugas mencatat nota dan minuta mengenai suatu kegiatan atau keputusan, kemudian membuat salinan dokumennya, baik yang bersifat publik maupun privat. Pada waktu itu, profesi scribe sangat dibutuhkan karena sebagian besar masyarakat buta huruf. ${ }^{3}$

\footnotetext{
1 Krisna Harahap, Konstitusi Republik Indonesia Menuju Perubahan ke-5, Grafiti Budi Utami, Bandung, 2009, hlm. 16.

2 G.H.S. Lumban Tobing, Peraturan Jabatan Notaris, Erlangga, Jakarta, 1982, hlm. 2.

3 Anke Dwi Saputro, Jati Diri Notaris Indonesia Dulu, Sekarang, Dan Di Masa Datang, Gramedia Pustaka Utama, Jakarta, hlm. 40.
} 
Kata "notaris" itu sendiri berasal dari kata "nota literaria" yang berarti tanda tulisan atau karakter yang digunakan untuk menulis atau menggambarkan ungkapan kalimat yang disampaikan nara sumber. Tanda atau karakter yang dimaksud adalah tanda yang digunakan dalam penulisan cepat (stenografie). Notaris yang menjadi penulis kerajaan ini mempunyai kedudukan sebagai pegawai istana, sehingga tidak sesuai dengan kedudukan notaris masa kini. Notaris juga ada dalam kekuasaan kepausan yang disebut "tabellio" dan "clericus notarius publics" yang memberikan bantuan dalam hubungan hukum keperdataan. ${ }^{4}$

Dalam perkembangannya, para tabelliones dan tabularii sering menyebut dirinya sebagai notarius, meskipun mereka tidak mempunyai surat pengangkatan dari kerajaan. Jadi, dapat dikatakan bahwa pada masa awal lahirnya, ada dua golongan notaris, yaitu notaris yang diangkat oleh kerajaan dan notaris swasta yang tidak diangkat oleh kerajaan. Notaris yang diangkat kerajaan mempunyai hak mengeluarkan akta autentik, sedangkan notaris yang tidak diangkat kerajaan hanya mempunyai hak untuk mengeluarkan akta di bawah tangan. Kemudian, para notaris yang diangkat kerajaan ini bergabung dalam sebuah badan yang disebut collegium. Para notaris (termasuk tabellio) yang diangkat kerajaan dipandang sebagai satu-satunya pejabat yang berhak membuat akta, baik di dalam maupun di luar pengadilan. ${ }^{5}$
Pada awal kelahiran jabatan notaris, telah terlihat jelas hakikatnya sebagai pejabat umum (private notary) yang ditugaskan oleh kekuasaan umum untuk melayani kebutuhan masyarakat terhadap alat bukti autentik yang memberikan kepastian hubungan hukum keperdataan. Jadi, sepanjang alat bukti autentik tetap diperlukan oleh sistem hukum negara, makajabatan notaris akan tetap diperlukan eksistensinya di tengah masyarakat. ${ }^{6}$

Notaris merupakan pejabatumumyang mempunyai tugas dan kewajiban untuk memberikan pelayanan dan konsultasi hukum kepada masyarakat. Bantuan hukum yang dapat diberikan oleh seorang notaris adalah dalam bentuk membuat alat bukti tertulis yang mempunyai kekuatan autentik, yaitu berupa akta autentik ataupun kewenangan lain sebagaimana dimaksud dalam undang-undang. ${ }^{7}$

Saat ini, keberadaan notaris telah diatur dalam undang-undang, yaituUU Nomor 30 Tahun 2004 tentang Jabatan Notaris, sebagaimana telah diubah dengan UU Nomor 2 Tahun 2014 tentang Perubahan atas UU Nomor 30 Tahun 2004 tentang Jabatan Notaris (selanjutnya disebut UUJN). UU Nomor 30 Tahun 2004 menggantikan peraturan sebelumnya, yaitu Peraturan Jabatan Notaris berdasarkan Stbl 1860-3 (Notaris Reglement) yang berlaku di Indonesia selama 244 tahun. Peraturan Jabatan Notaris ini merupakan pengganti Instructie voor Notarissen in Indonesia (Stbl 182211). Tahun 1620, pada masa Republiek

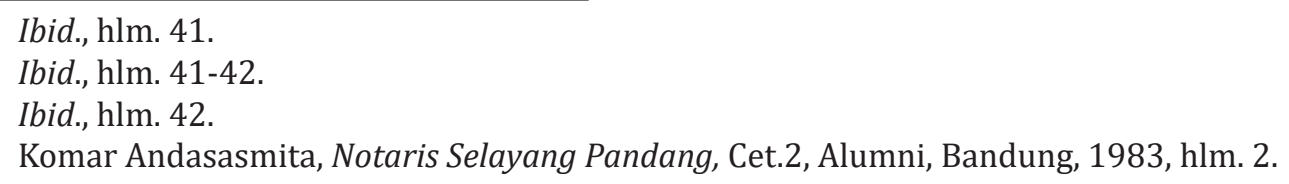


der Verenigde Nederlanden, diangkat seorang notaris pertama di Indonesia, yaitu Melchior Kerchem. ${ }^{8}$ Notaris adalah pejabat umum yang berwenang untuk membuat akta autentik dan kewenangan lainnya. Kewenangan dimaksud adalah kewenangan sebagaimana diatur dalam Pasal 15 UUJN. Kedudukan notaris sebagai pejabat umum, dalam arti kewenangan yang ada pada notaris, tidak pernah diberikan kepada pejabat-pejabat lainnya. Sepanjang kewenangan tersebut tidak menjadi kewenangan pejabat-pejabat lain dalam membuat akta autentik dan kewenangan lainnya, maka kewenangan tersebut menjadi kewenangan notaris.

Selanjutnya, Pasal 15 ayat (3) UUJN menyatakan bahwa selain kewenangan sebagaimana dimaksud pada ayat (1) dan ayat (2), notaris mempunyai kewenangan lain yang diatur dalam peraturan perundang-undangan. Jadi, selain kewenangan yang diatur dalam UUJN, notaris juga memiliki kewenangan yang ditegaskan dalam peraturan perundangundangan lain (di luar UUJN). Dalam hal ini, peraturan perundang-undangan yang bersangkutan menegaskan agar perbuatan hukum tertentu wajib dibuat dengan akta notaris.

Sesuai dengan ketentuan Pasal 15 UUJN, selain membuat akta autentik, notaris juga mengesahkan dan membukukan surat-surat yang dibuat di bawah tangan, yaitu surat yang dibuat sendiri oleh perseorangan atau oleh para pihak di atas kertas yang bermaterai cukup, dengan jalan mendaftarkan ke dalam daftar buku yang dibuat dan disediakan khusus untuk itu oleh notaris. Selain itu, notaris dalam jabatannya wajib memberikan penyuluhan hukum dan memberikan konsultasi hukum kepada masyarakat.

Akta autentik sebagai alat bukti terkuat dan terpenuh, mempunyai peranan penting dalam setiap hubungan hukum dalam kehidupan masyarakat. Dalam berbagai hubungan bisnis, kegiatan di bidang perbankan, pertanahan, kegiatan sosial, dan lain-lain, diperlukan adanya pembuktian tertulis berupa akta autentik. ${ }^{9}$ Hal ini sejalan dengan perkembangan tuntutan akan kepastian hukum dalam berbagai hubungan ekonomi dan sosial, baik pada tingkat regional, nasional, maupun internasional. Akta autentik yang menentukan secara jelas hak dan kewajiban para pihak akan menjamin kepastian hukum sekaligus diharapkan dapat menghindari terjadinya sengketa. ${ }^{10}$

Pasal 1 angka 7 UUJN menyebutkan bahwa akta notaris adalah akta autentik yang dibuat oleh atau di hadapan notaris menurut bentuk dan tata cara yang ditetapkan dalam undang-undang ini. Ketentuan ini merupakan penegasan dari Pasal 1868 KUH Perdata, yang menyatakan bahwa akta autentik adalah suatu akta yang di dalam bentuk yang ditentukan oleh undang-undang, dibuat oleh atau di hadapan pegawai-pegawai umum yang berkuasa untuk itu di tempat di mana akta dibuatnya. Berdasarkan ketentuan

8 G.H.S. Lumban Tobing, Op. Cit., hlm. 1-2.

9 Pasal 1867 KUH Perdata menyatakan bahwa pembuktian dengan tulisan dilakukan dengan tulisan autentik atau dengan tulisan di bawah tangan.

10 G.H.S. Lumban Tobing, Op. Cit., hlm. 38-39. 
tersebut, diketahui bahwa salah satu akta autentik adalah akta notaris. Dalam menjalankan tugas dan kewajibannya, notaris dituntut untuk memberikan jaminan kepastian hukum dan pelayanan yang profesional. Dalam mewujudkan 2 (dua) sisi pekerjaan yang mengandung banyak risiko, diperlukan pengetahuan hukum yang cukup dan ketelitian serta tanggung jawab yang tinggi. Untuk itu, dalam praktik, notaris diwajibkan untuk senantiasa menjunjung tinggi hukum serta bertindak sesuai dengan sumpah jabatan.

Dalam konteks notaris sebagai pejabat umum, akta relaas atau akta pejabat (ambtelijke akten) adalah akta yang dibuat oleh (door enn) notaris berdasarkan pengamatan yang dilakukan notaris tersebut. Akta jenis ini di antaranya akta berita acara rapat umum pemegang saham perseroan terbatas, akta pendaftaran atau inventarisasi harta peninggalan, dan akta berita acara penarikan undian. Sementara itu, akta partij (party acten) dimaksudkan sebagai akta yang dibuat di hadapan notaris berdasarkan kehendak atau keinginan para pihak. dalam kaitannya dengan perbuatan hukum yang dilakukan oleh para pihak tersebut. Akta jenis ini di antaranya akta jual beli, akta sewamenyewa, akta perjanjian kredit, dan akta keterangan penetapan risalah rapat umum pemegang saham. ${ }^{11}$

Notaris juga berperan untuk memberikan nasihat hukum yang sesuai dengan permasalahan yang ada. Apa pun nasihat hukum yang diberikan notaris kepada para pihak dan kemudian dituangkan ke dalam akta, tetap sebagai keinginan atau keterangan para pihak yang bersangkutan, dan bukan sebagai keterangan atau pernyataan notaris. ${ }^{12}$

Dalam praktik, kadang-kadang para pihak atau penghadap memberikan keterangan/pernyataan yang tidak benar (palsu) kepada notaris. Notaris tidak mengetahui bahwa keterangan/ pernyataan tersebut adalah keterangan/ pernyataan yang palsu. Notaris menuangkan keterangan/pernyataan tersebut dalam bentuk akta notaris. Selanjutnya, pihak lain yang merasa dirugikan mempermasalahkan akta notaris tersebut, bahkan melaporkan notaris kepada aparat penegak hukum atas dasar melakukan tindak pidana. Dalam kasus seperti itu, permasalahan yang timbul adalah, apakah notaris dapat diminta pertanggungjawaban berdasarkan hukum pidana?

Jika notaris melakukan tindak pidana, maka tentu saja dapat diminta pertanggungjawaban di bawah hukum pidana. Hal ini sejalan dengan pandangan Hans Kelsen bahwa konsep yang berhubungan dengan kewajiban hukum adalah konsep tanggung jawab hukum, yaitu seseorang bertanggung jawab secara hukum atas suatu perbuatan tertentu atau orang tersebut memikul tanggung jawab hukum. ${ }^{13}$

$11 \quad$ Ibid., hlm. 51-52.

12 Habib Adjie, Hukum Notaris Indonesia (Tafsir Tematik Terhadap UU No. 30 Tahun 2004 Tentang Jabatan Notaris), Cet. Pertama, Refika Aditama, Bandung, 2009, hlm. 24.

13 Kelsen, Hans, General Theory Of Law and State, Teori Umum Hukum Dan Negara, Dasar-Dasar Ilmu Hukum Normatif Sebagai Ilmu Hukum Deskriptif-Empirik, Alih Bahasa oleh Soemardi, BEE Media Indonesia, Jakarta, 2007, hlm. 81. 
Hal yang menjadi permasalahan terkait dengan tugas notaris adalah pembuatan akta notaris yang didasarkan pada keterangan/pernyataan palsu. Pertanyaan pokoknya adalah, dapatkah notaris diminta pertanggungjawaban pidana terkait dengan pembuatan akta yang didasarkan pada keterangan palsu? Terkait dengan masalah tersebut, UUJN tidak mengatur tindak pidana yang terkait dengan jabatan notaris. Dengan demikian, jika ada tindak pidana yang terkait dengan tugas seorang notaris, maka diberlakukan ketentuan KUHP.

Penulis mengidentifikasikan masalahmasalah yang diteliti sebagai berikut:

1. Apakah notaris dapat diminta pertanggungjawaban pidana atas akta yang dibuat berdasarkan keterangan palsu?

2. Bagaimanakah akibat hukum yang timbul terhadap akta notaris yang didasarkan pada keterangan palsu?

3. Apakah pertanggungjawaban pidana notaris perlu diatur dalam UU Jabatan Notaris?

\section{B. PEMBAHASAN}

1. Pertanggungjawaban

Pidana

Notaris dalam Pembuatan Akta yang Didasarkan pada Keterangan Palsu Dihubungkan dengan UU Jabatan Notaris dan KUHP

Sebagaimana yang telah diuraikan pada bab sebelumnya, menurut Moeljatno bahwa perbuatan pidana adalah perbuatan yang dilarang oleh suatu aturan hukum larangan mana disertai ancaman (sanksi) yang berupa pidana tertentu, bagi barangsiapa melanggar larangan tersebut. Dapat juga dikatakan bahwa perbuatan pidana adalah perbuatan yang oleh suatu aturan hukum dilarang dan diancam pidana asal saja dalam pada itu diingat bahwa larangan ditujukan kepada perbuatan, (yaitu suatu keadaan atau kejadian yang ditimbulkan oleh kelakuan orang), sedangkan ancaman pidananya ditujukan kepada orang yang menimbulkannya kejadian itu. Antara larangan dan ancaman pidana ada hubungan yang erat, oleh karena antara kejadian dan orang yang menimbulkan kejadian itu, ada hubungan yang erat pula. Yang tidak dapat dipisahkan dari yang lain. Oleh karena itu untuk adanya perbuatan pidana harus ada unsur-unsur:

a. Perbuatan (manusia);

b. Yang memenuhi rumusan dalam undang-undang (merupakan syarat formil), dan;

c. Bersifat melawan hukum (merupakan syarat material).

Syarat formil ini mutlak harus ada terkait dengan adanya asas legalitas, (tiada pidana kecuali ada aturan hukum yang mengaturnya). Pasal 1 ayat (1) KUHP, dan syarat material juga harus ada, karena perbuatan itu harus betulbetul dirasakan oleh masyarakat sebagai perbuatan yang tidak boleh atau tidak patut dilakukan, karena bertentangan dengan atau menghambat tercapainya tata tertib dalam pergaulan masyarakat yang dicita-citakan oleh masyarakat tersebut. Moeljatno berpendapat bahwa kesalahan dan kemampuan bertanggungjawab dari pelaku tidak termasuk unsur perbuatan pidana, karena hal-hal tersebut melekat pada orang yang berbuat.

Tindak pidana tidak berdiri sendiri, ia baru bermakna apabila terdapat 
pertanggungjawaban pidana. Hal ini berarti bahwa setiap orang yang melakukan tindak pidana tidak dengan sendirinya harus dipidana. Untuk dapat dipidana harus ada pertanggungjawaban pidana. Pertanggungjawaban pidana lahir dengan diteruskannya celaan (verwijbaarheid) yang obyektif terhadap perbuatan yang dinyatakan sebagai tindak pidana berdasarkan hukum pidana yang berlaku, dan secara subyektif kepada pembuat yang memenuhi persyaratan untuk dapat dikenai pidana karena perbuatan tersebut. ${ }^{14}$

Dasar adanya tindak pidana adalah asas legalitas sedangkan dasar dapat dipidananya pembuat adalah asas kesalahan. Ini berarti bahwa pembuat tindak pidana hanya akan dipidana jika ia mempunyai kesalahan dalam melakukan tindakan pidana tersebut. Kapan seseorang dikatakan mempunyai kesalahan merupakan hal yang menyangkut masalah pertanggungjawaban pidana. Seseorang mempunyai kesalahan bilamana pada waktu melakukan tindak pidana, dilihat dari segi kemasyarakatan ia dapat dicela oleh karena perbuatan tersebut.

Selanjutnya Sudarto menyatakan bahwa, menurut beliau disini berlaku asas "tiada pidana tanpa kesalahan" (keine strafe ohne schuld atau geen straf zonder schuld atau nulla poena sine culpa). "Culpa" disini dalam arti luas, meliputi juga kesengajaan. Kesalahan, yang dimaksud adalah keadaan jiwa seseorang yang melakukan perbuatan dan perbuatan yang dilakukan itu sedemikian rupa, sehingga orang itu patut dicela.
Seorang notaris bisa saja terlibat dalam pertanggungjawaban pidana dan mungkin saja dapat dimintakan pertanggungjawaban pidana apabila memenuhi unsur-unsur yang dilarang menurut hukum. Adanya kemampuan bertanggungjawab pada si pembuat, hubungan batin antara si pembuat dan perbuatannya yang berupa kesengajaan (dolus) atau kealpaan (culpa) dan tidak adanya alasan penghapusan kesalahan atau tidak ada alasan pemaaf.

Terkait dengan pertanggungjawaban pidana seorang notaris, pertanyaan yang timbul adalah, dalam hal bagaimanakah seorang notaris dapat diminta pertanggungjawaban pidana jika ia membuat akta yang didasarkan pada keterangan palsu? Jawaban atas pertanyaan ini, tentu saja harus mengacu pada peraturan yang berlaku. Mengacu pada peraturan yang berlaku, diketahui bahwa seorang notaris dapat dimintai pertanggungjawaban pidana dalam hal pembuatan akta yang didasarkan pada keterangan palsu, dan aturan yang ada kaitannya dengan permasalahan diatas adalah Pasal 263 ayat (1), 264 ayat (1) ke-1, atau 266 ayat (1) KUHP jo. Pasal 55 ayat (1) KUHP. Sedangkan ketentuan UUJN tidak mengatur tindak pidana yang dilakukan notaris.

Timbul pertanyaan apakah syaratnya seseorang, dalam hal ini notaris dapat disebut sebagai ikut terlibat dan ikut bertanggungjawab dengan peserta lainnya di dalam mewujudkan tindak pidana?
a. Dipandang dari sudut subjektif, ada 2 syaratnya:

14 Penjelasan Pasal 36 Rancangan KUHP Tahun 2005. 
1) adanya hubungan batin (kesengajaan) dengan tindak pidana yang hendak diwujudkan, artinya kesengajaan dalam berbuat diarahkan pada terwujudnya tindak pidana. Di sini, sedikit atau banyak ada kepentingan untuk terwujudnya tindak pidana.

2) Adanya hubungan batin (kesengajaan) seperti mengetahui antara dirinya dengan peserta lainnya, dan bahkan dengan apa yang diberbuat oleh peserta lainnya.

b. Dipandang dari sudut objektif, ialah bahwa perbuatan orang itu ada hubungan dengan terwujudnya tindak pidana, atau dengan kata lain wujud perbuatan orang itu secara objektif ada perannya/pengaruh positif baik besar atau kecil, terhadap terwujudnya tindak pidana.

Sebaliknya menurut ajaran yang kedua ini yaitu objektif, yang menitikberatkan pada wujud perbuatan apa serta sejauh mana peran dan andil serta pengaruh positif dari wujud perbuatan itu terhadap timbulnya tindak pidana yang dimaksudkan, yang menentukan seberapa berat tanggungjawab yang dibebannya terhadap terjadinya tindak pidana. ${ }^{15}$

Untuk dapat dipertanggungjawabkan secara pidana, seorang notaris harus memenuhi unsur-unsur sebagai berikut:

a. Melakukan tindak pidana. Dalam hal ini, seorang notaris diduga melakukan tindak pidana yang menyebabkan terbitnya akta notaris yang didasarkan pada keterangan palsu. Tanpa adanya tindak pidana, tidak mungkin seorang notaris dapat dimintai pertanggungjawaban berdasarkan hukum pidana;

b. Memiliki kemampuan untuk bertanggung jawab. Untuk dapat diminta pertanggungjawaban di bawah hukum pidana, seorang notaris harus memiliki kemampuan untuk bertanggung jawab. Sebagaimana dikemukakan sebelumnya bahwa salah satu syarat untuk adanya kesalahan dalam arti luas adalah, adanya kemampuan bertanggung jawab, yang hakikatnya merupakan keadaan batin pelaku, yaitu keadaan batin yang sedemikian rupa sehingga menjadi dasar pembenar untuk penjatuhan pidana. Hal ini berarti, seseorang dapat diminta pertanggungjawaban dibawah hukum pidana apabila orang tersebut dianggap mampu bertanggung jawab. Ketentuan ini juga berlaku bagi notaris, artinya seorang notaris dapat diminta pertanggungjawaban pidana jika ia memiliki kemampuan untuk bertanggung jawab, dan apabila ia berkehendak, mempunyai tujuan dan kepentingan untuk terwujudnya tindak pidana tersebut;

c. Dengan kesengajaan atau kealpaan. Tindak pidana yang dilakukan seorang notaris dalam kasus pembuatan akta yang didasarkan pada keterangan palsu dapat berupa kesengajaan atau kealpaan. Untuk dapat diminta pertanggungjawaban pidana, seorang

\footnotetext{
15 Adami Chazawi, Pelajaran Hukum Pidana(Bagian 3) Percobaan \& Penyertaan, PT. Raja Grafindo Persada, Jakarta, 2008, hlm. 75.
} 
notaris harus mempunyai kesalahan, baik yang dilakukan secara sengaja maupun karena kealpaan. Dalam kasus pembuatan akta yang didasarkan pada keterangan palsu, seorang notaris mungkin dapat saja secara sengaja turut serta dalam pembuatan akta tersebut. Namun apakah sikapbatinnya dia menghendaki terwujudnya suatu tindak pidana tersebut. Dalam hal ini, notaris tersebut menghendaki dilakukannya tindak pidana (pemalsuan) serta menyadari dan mengetahui akibat perbuatannya, yang tentu saja merugikan pihak lain dan hal ini harus dapat dibuktikan. Selain itu, seorang notaris bisa saja lalai ketika membuat akta notaris. Misalnya, notaris tidak teliti/hati-hati dalam memeriksa alat bukti yang diperlihatkan para pihak/ penghadap atau tidak berhati-hati dalam menanggapi keterangan para pihak/penghadap; dan

d. Tidak ada alasan pemaaf. Seorang notaris dapat diminta pertanggungjawaban pidana jika tidak ada alasan pemaaf. Apabila dalam kasus pembuatan akta yang didasarkan pada keterangan palsu yang diduga melibatkan notaris, tidak ditemukan adanya alasan pemaaf dalam diri notaris yang bersangkutan, maka ia dapat diminta pertanggungjawaban pidana.

Penyertaan (deelneming) adalah $^{16}$ pengertian yang meliputi semua bentuk turut serta/terlibatnya orang atau orangorang baik secara psikis maupun fisik dengan melakukan masing-masing perbuatan sehingga melahirkan suatu tindak pidana. Orang-orang yang terlibat dalam kerja sama yang mewujudkan tindak pidana, perbuatan masing-masing dari mereka berbeda satu sama lain, demikian juga bisa tidak sama apa yang ada dalam sikap batin mereka terhadap tindak pidana maupun terhadap peserta yang lain. Tetapi dari perbedaan-perbedaan yang ada pada masing-masing itu terjalin suatu hubungan yang sedemikian rupa eratnya, di mana perbuatan yang satu menunjang perbuatan yang lainnya, yang semuanya mengarah pada satu ialah terwujudnya tindak pidana.

Masalah penyertaan atau deelneming dapat dibagi menurut sifatnya dalam:

a. Bentuk penyertaan berdiri sendiri.

Yang termasuk jenis ini adalah mereka yang melakukan dan yang turut serta melakukan tindak pidana. Pertanggungjawaban masing-masing peserta dinilai atau dihargai sendirisendiri atas segala perbuatan atau tindakan yang dilakukan.

b. Bentuk penyertaan yang tidak berdiri sendiri.

Yang termasuk dalam jenis ini adalah pembujuk, pembantu dan yang menyuruh untuk melakukan sesuatu tindak pidana. Pertanggungjawaban dari peserta yang satu digantungkan pada perbuatan peserta lain.

Apabila oleh peserta lain dilakukan perbuatan yang dapat dihukum peserta yang satu juga dapat dihukum. Di dalam KUHP terdapat dua bentuk penyertaan, ialah yang disebut sebagai: ${ }^{17}$

\footnotetext{
$16 \quad$ Ibid., hlm. 73.

17 Ibid., hlm. 205.
} 
a. Pembuat atau dader dalam Pasal 55 KUHP.

b. Pembantu atau medeplichtigheiddiatur dalam Pasal 56 KUHP.

Pasal 55 ayat (1) KUHP menyatakan, dipidana sebagai pelaku (dader) sesuatu tindak pidana, mereka yang melakukan, yang menyuruh melakukan, dan yang turut serta melakukan perbuatan. Apakah keterlibatan notaris dalam pembuatan akta yang didasarkan pada keterangan palsu, dapat dikenai Pasal 55 ayat (1) KUHP tersebut sebagai delik penyertaan.

Dalam Pasal 55 KUHP menyebutkan empat golongan yang dapat dipidana:

a. Pelaku atau pleger;

b. Menyuruh melakukan atau doenpleger;

c. Turut serta atau medepleger;

d. Penganjur atau uitlokker.

Pasal 56 KUHP menyebutkan siapa yang dipidana sebagai pembantu suatu kejahatan, yaitu ada dua golongan;

a. mereka yang sengaja memberi bantuan pada waktu kejahatan dilakukan;

b. mereka yang memberi kesempatan sarana atau keterangan untuk melakukan kejahatan.

Pasal 266 ayat (1) KUHP menyatakan, barangsiapa menyuruh masukkan keterangan palsu ke dalam suatu akta autentik mengenai sesuatu hal yang kebenarannya harus dinyatakan oleh akta itu, dengan maksud untuk memakai atau menyuruh orang lain memakai akta itu seolah-olah keterangannya sesuai dengan kebenaran, diancam, jika pemakaian itu dapat menimbulkan kerugian, dengan pidana penjara paling lama 7 (tujuh) tahun.
Lebih jauh penulis mencermati dan menganalisis, dalam akta pihak (Partijn akten) dimana akta ini merupakan akta yang dibuat dihadapan notaris dalam hal mana notaris menuangkan ke dalam akta autentik segala kehendak atau keinginan berdasarkan kesepakatan para pihak baik berupa pernyataan, perjanjian ataupun ketetapan, bahwa apabila notaris dinyatakan sebagai "orang yang turut serta menyuruh memasukkan keterangan palsu ke dalam suatu akta otentik..., maka suatu perbuatan memasukkan keterangan palsu tersebut harus ada hubungan batin kesengajaan dengan tindak pidana yang dilakukan dan secara sadar bekerjasama dengan para pihak yang dilakukan secara fisik untuk mewujudkan tindak pidana tersebut. Apabila dinyatakan notaris menyuruh memasukkan keterangan palsu ke dalam akta yang dibuatnya, apa kepentingan serta keuntungan bagi notaris tersebut. Oleh karenanya hal ini merupakan suatu hal yang mustahil dilakukan oleh seorang notaris, yang apabila dilakukan, maka sama halnya dengan mencelakaan dirinya sendiri, menghancurkan sendiri profesinya dan kehidupannya. Kemudian apakah mungkin para pihak yang menghadap notaris untuk menyuruh membuat akta autentik, akan mau disuruh oleh notaris untuk menempatkan keterangan palsu dalam akta yang dibuat dihadapan notaris, kalaupun mau itu merupakan kesepakatan mereka bersama yang merupakan kehendak para pihak, dan notaris hanya bertugas menuangkan atau memasukkan suatu pernyataan/keterangan dan perjanjian yang sudah disepakati oleh para pihak ke dalam bentuk akta autentik. 
Maka dalam hal ini notaris tidak dapat dikatakan sebagai dader atau pelaku. ${ }^{18}$

Pasal 266 ayat (1) KUHP,dapat dilihat yang menjadi unsur-unsurnya yaitu:

a. Barangsiapa;

b. Menyuruh masukkan keterangan palsu ke dalam suatu akta autentik;

c. Dengan maksud untuk memakai atau menyuruh orang lain memakai akta itu seolah-olah keterangannya sesuai dengan kebenaran;

d. Perbuatan itu menimbulkan kerugian. Kemudian Pelakunya sesuai dengan Pasal 55 ayat (1) ke-1 KUHP yaitu:

a. mereka yang melakukan;

b. mereka yang menyuruh melakukan;

c. mereka yang turut serta dalam melakukan perbuatan.

Apakah Notaris dapat dijatuhi hukuman berdasarkan Pasal 266 ayat (1) KUHP jo Pasal 55 ayat (1) ke-1 KUHP tersebut diatas?

Dalam hal unsur "barang siapa" di dalam Pasal 266 ayat (1) KUHP, harus diartikan sebagai pelaku atau subjek tindak pidana, yang dalam hal ini notaris adalah sebagai pembuat akta autentik dalam partijn akten atau akta partai, tidak dapat dikatakan sebagai subjek (pelaku) dalam Pasal 266 ayat (1) KUHP tersebut, yang menjadi pelaku adalah para pihak yang menyuruh membuat akta autentik, merekalah yang menyuruh melakukan membuat keterangan palsu, sedangkan pejabat notaris hanya orang yang disuruh melakukan memasukkan keterangan palsu ke dalam akta autentik. Kemudian, berdasarkan Pasal 266 ayat (1) KUHP, tindakan subjek (pelaku) yaitu menyuruh memasukkan suatu keterangan palsu ke dalam suatu akte otentik, sehingga kata "menyuruh" dalam Pasal 266 ayat (1) KUHP ditafsirkan bahwa kehendak itu hanya ada pada si penyuruh (pelaku/subjek), sedangkan pada yang disuruh tidak terdapat kehendak untuk memasukkan keterangan palsu dan seterusnya.

Selanjutnya, "penyertaan" sebagaimana diatur Pasal 55 ayat (1) ke-1 KUHP yang kemudian dihubungan dengan Pasal 266 ayat (1) KUHP, hal inipun sulit untuk dibuktikan keikutsertaan notaris dalam perbuatan pidana, mengklasifikasikan "pelaku tindak pidana" yaitu mereka yang melakukan, yang menyuruh melakukan dan yang ikut serta melakukan tindak pidana. Sehingga jika seorang notaris didakwakan sebagai pelaku "Penyertaaan" yang dihubungkan dengan Pasal 266 ayat (1) KUHP, maka dapat dikontruksikan bahwa Notaris tersebut sebagai pelaku:

- "melakukan menyuruh menempatkan keterangan palsu ke dalam suatu akta otentik ....";

- "menyuruh melakukan menyuruh menempatkan keterangan palsu ke dalam suatu akta otentik ...";

- "ikut serta menyuruh menempatkan keterangan palsu ke dalam suatu akta otentik ...."

Jika seorang Notaris dinyatakan sebagai "orang yang melakukan menyuruh menempatkan keterangan palsu ke dalam suatu akta otentik ..., adalah suatu hal yang mustahil dilakukan oleh seorang Notaris, karena:

18 Alvy Syahrin, Kesuksesan: Membuat Orang Suksses, http:alvyprofdr.blogspot.com/2010/11/notarispelaku-tindak-pidana-pasal-266.html, diakses tanggal 10 Agustus 2014 pukul 10.00 WIB. 
a. akta yang dibuat berupa akta partie/ akta pihak, yaitu akta yang dibuat oleh notaris berdasarkan atas permintaan para pihak untuk mencatat atau menuliskan segala sesuatu hal yang dibicarakan oleh pihak berkaitan dengan tindakan hukum.

b. "orang yang menyuruh melakukan" menurut Pasal 55 ayat (1) ke-1 KUHP, yaitu adalah mereka yang melakukan semua unsur tindak pidana, artinya:

- jika dikaitkan dengan kedudukan seorang notaris yang membuat akte partie, adalah suatu hal yang berlebihan dan tidak mungkin bisa dilakukan, sebab tidak mengkin notaris akan menyuruh para pihak untuk menempatkan keterangan palsu di dalam akta otentik yang dibuat oleh notaris tersebut, melainkan hal itu merupakan keinginan para pihak yang menyuruh notaris membuat akta.

- jika Notaris, dinyatakan sebagai "orang yang menyuruh melakukan menyuruh menempatkan keterangan palsu ke dalam suatu akta otentik ...", juga suatu hal yang mustahil dilakukan oleh seorang Notaris, oleh karena ke dua belah pihak yang datang kepada Notaris untuk membuatkan akta tersebut, dan hal tersebut merupakan kesepakatan ke dua belah pihak untuk dituangkan di dalam akta, serta suatu hal yang aneh juga notaris sebagai pejabat yang berwenang merupakan orang yang mempunyai kehendak melakukan tindak pidana menyuruh ke dua belah pihak untuk menempatkan keterangan palsu pada akta yang mereka kehendaki bersama, karena keterangan yang ada di dalam akta merupakan kesepakatan ke dua belah pihak.

Berdasarkan Pasal 1 ayat (1) dan Pasal 15 UUJN menyatakan bahwa notaris berwenang membuat akta autentik. Selanjutya, notaris dalam menjalankan tugasnya perlu mendapatkan perlindungan dan jaminan demi tercapainya kepastian hukum, sehingga dalam menjalankan tugasnya notaris diatur dalam ketentuan UUJN, sehingga UUJN merupakan lex specialis dari KUHP, dan bentuk hubungan notaris dengan para penghadap harus dikaitkan dengan Pasal 1869 KUH Perdata. Dimana suatu akta yang karena tidak berkuasa atau tidak cakapnya atau karena suatu cacad dalam bentuknya, tidak dapat diperlakukan sebagai akta autentik, namun demikian mempunyai kekuatan sebagai tulisan dibawah tangan jika ia ditandatangani oleh para pihak.

Dengan demikian menjatuhkan hukuman terhadap seorang Notaris yang membuat akta partie berdasarkan Pasal 266 ayat (1) KUHP (apalagi di junctokan dengan Pasal 55 ayat (1) ke-1 KUHP), sebenarnya merupakan hal yang tidak tepat, karena unsur-unsur dari pasal-pasal tersebut tidak terpenuhi dan unsur-unsur perbuatan pidana sulit dibuktikan bila dikaitkan dengan fungsi dan kewenangan notaris yang di dasarkan kepada UUJN, dan keliruan dalam menerapkan hukum akan berakibat kriminalisasi terhadap pekerjaan/tugas notaris. Penerapan Pasal 266 ayat (1) KUHP terhadap notaris menjadikan 
perbuatan notaris dalam melaksanakan kewenangan membuat akta sebagai perbuatan pidana, tanpa memperhatikan aturan hukum yang berkaitan dengan tata cara pembuatan akta, menunjukkan telah terjadi kesalahanpahaman atau salah menafsirkan tentang kedudukan notaris dan juga akta notaris adalah sebagai alat bukti dalam Hukum Perdata.

Akan tetapi dalam konteks notaris sebagai pejabat umum, akta relaas atau akta pejabat (ambtelijke akten) yaitu akta yang dibuat oleh (door enn) notaris berdasarkan pengamatan yang dilakukan notaris tersebut, misalnya akta berita acara rapat umum pemegang saham perseroan terbatas, akta pendaftaran atau inventarisasi harta peninggalan, dan akta berita acara penarikan undian, hal ini mungkin saja dapat dilakukan pemalsuan oleh notaris yang membuat akta tersebut karena adanya kesengajaan baik berupa kelalai ataupun kealpaan atau kesalahan.

Mengenai hal tersebut notaris dapat diancam pidana melanggar ketentuan Pasal 264 ayat(1) ke-1 KUHP yaitu Pemalsuan surat terhadap akta-akta autentik dengan ancaman pidana penjara paling lama delapan tahun.

Pasal 264 ayat (1) ke-1 KUHP tersebut menyatakan bahwa Pemalsuan surat diancam dengan pidana penjara paling lama delapan tahun, jika dilakukan terhadap akta-akta otentik.

Dengan demikian notaris bisa saja dimintai pertanggungjawaban pidana terkait dengan pembuatan akta yang didasarkan pada keterangan palsu jika perbuatan notaris memenuhi rumusan unsur tindak pidana pemalsuan dalam KUHP, khususnya Pasal 264 ayat (1) ke-1
KUHP, yaitu terhadap akta relaas atau akta pejabat (ambtelijke akten), namun notaris tidak dapat dimintai pertanggungjawaban pidana notaris terhadap akta partai (partijn akten) berdasarkan Pasal 266 ayat (1) juncto Pasal 55 ayat (1) KUHP.

UUJN tidak mengatur tindak pidana yang terkait dengan jabatan notaris, sehingga tidak ada ketentuan dalam UUJN yang dapat digunakan sebagai dasar pertanggungjawaban pidana notaris. Notaris dapat diminta pertanggungjawaban pidana berdasarkan Pasal 264 ayat (1) ke-1 KUHP jika secara sengaja atau lalai dalam pembuatan akta relaas atau akta pejabat (ambtelijke akten) yaitu akta yang dibuat oleh (door enn) notaris berdasarkan pengamatan yang dilakukan notaris tersebut, sehingga merugikan pihak lain, akan tetapi tetap mengindahkan fungsi dan wewenang notaris berdasarkan UUJN, sebagai pejabat yang diangkat oleh negara dalam melayani masyarakat dalam pembuatan akta autentik yang merupakan alat bukti untuk terjaminnya suatu kepastian hukum.

Untuk dapat dipertanggungjawabkan secara pidana, seorang notaris harus memenuhi unsur-unsur: melakukan tindak pidana; memiliki kemampuan untuk bertanggung jawab; dengan kesengajaan atau kealpaan; dan tidak ada alasan pemaaf. Yurisprudensi Mahkamah Agung (Putusan Mahkamah Agung No. 702 K/Sip/1973, tanggal 5 September 1973) menyatakan: "Notaris fungsinya hanya mencatat/menuliskan apa-apa yang dikehendaki dan dikemukakan oleh para pihak yang menghadap notaris tersebut. Tidak ada kewajiban bagi notaris untuk menyelidiki secara materil apa-apa (hal- 
hal) yang dikemukakan oleh penghadap di hadapan notaris tersebut"; ${ }^{19}$

Kemudian, akta notaris sebagai akta otentik mempunyai kekuatan pembuktian yang sempurna sehingga para pihak yang membaca akta tersebut harus melihat apa adanya dan notaris tidak perlu membuktikan kebenaran atas akta yang dibuat di hadapan atau oleh notaris. Apabila ada pihak yang meragukan kebenaran isi akta tersebut, maka pihak tersebut yang wajib membuktikan ketidak benaran isi akta tersebut.

\section{Akibat Hukum terhadap Akta Notaris yang Didasarkan pada Keterangan Palsu}

Penilaian terhadap akta notaris harus dilakukan dengan asas praduga sah (presumptio iustae causa). Asas ini dapat digunakan untuk menilai akta notaris, yaitu akta notraris harus dianggap sah sampai ada pihak yang menyatakan bahwa akta tersebut tidak sah. Untuk menyatakan atau menilai akta tersebut tidak sah harus dengan mengajukan gugatan ke Pengadilan Negeri. Selama dan sepanjang gugatan berjalan sampai dengan ada putusan pengadilan yang mempunyai kekuatan hukum yang tetap, maka akta notaris tetap sah dan mengikat para pihak atau siapa saja yang berkepentingan dengan akta tersebut. $^{20}$

Menerapkan asas praduga sah untuk akta notaris, maka berlaku ketentuan yang termuat dalam Pasal 84 UUJN,yaitu akta yang bersangkutan hanya mempunyai kekuatan pembuktian sebagai akta di bawah tangan tidak diperlukan lagi, sehingga kebatalan akta notaris hanya berupa dapat dibatalkan atau batal demi hukum.Asas praduga sah terhadap akta notaris berkaitan dengan akta yang dapat dibatalkan, merupakan suatu tindakan mengandung cacat, yaitu tidak berwenangnya notaris untuk membuat akta secara lahiriah, formal, dan material, serta tidak sesuai dengan aturan hukum tentang pembuatan akta notaris.Asas ini tidak dapat digunakan untuk menilai akta notaris batal demi hukum, karena akta batal demi hukum dianggap tidak pernah dibuat. $^{21}$

Dengan demikian, dengan alasan tertentu sebagaimana dikemukakan di atas, maka kedudukan akta notaris adalah: ${ }^{22}$

a. Dapat dibatalkan;

b. Batal demi hukum;

c. Mempunyai kekuatan pembuktian sebagai akta di bawah tangan;

d. Dibatalkan oleh para pihak sendiri; dan

e. Dibatalkan oleh putusan pengadilan yang telah mempunyai kekuatan hukum yang tetap karena penerapan asas praduga sah.

Sehubungan dengan pembatalan akta notaris, perlu dikemukakan ketentuan Pasal 84 UUJN. Menurut Pasal 84 UUJN bahwa tindakan pelanggaran yang dilakukan notaris terhadap ketentuan

\footnotetext{
19 Alvy Syahrin, Kesuksesan: Membuat Orang Suksses, http:alvyprofdr.blogspot.com/ 2010/11/notarispelaku-tindak-pidana-pasal-266.html,diakses tanggal 10 Agustus 2014 pukul 10.00 WIB.

20 Habib Adjie, Op. Cit., hlm. 140.

21 Ibid., hlm. 141.

22 Ibid.
} 
sebagaimana dimaksud dalam Pasal 16 ayat (1) huruf i, Pasal 16 ayat (1) huruf k, Pasal 41, Pasal 44, Pasal 48, Pasal 49, Pasal 50, Pasal 51, atau Pasal 52 yang mengakibatkan suatu akta hanya mempunyai kekuatan pembuktian sebagai akta di bawah tangan atau suatu akta menjadi batal demi hukum dapat menjadi alasan bagi pihak yang menderita kerugian untuk menuntut penggantian biaya, ganti kerugian, dan bunga kepada notaris.

Adapun hal-hal yang dimaksudkan dalam Pasal 84 UUJN adalah sebagai berikut:

a. Notaris tidak membuat daftar akta yang berkenaan dengan wasiat menurut urutan waktu pembuatan akta setiap bulan;

b. Notaris tidak mencatat dalam repertorium tanggal pengiriman daftar wasiat pada setiap akhir bulan;

c. Notaris melanggar ketentuan Pasal 38, Pasal 39, dan Pasal 40 UUJN. Pasal 38 mengatur bentuk dan sifat akta notaris yang terdiri dari awal akta (kepala akta), badan akta, dan akhir akta (penutup akta). Pasal 39 mengatur syarat-syarat penghadap dan Pasal 40 mengatur syarat-syarat saksi;

d. Notaris melanggar Pasal 44 UUJN yang mengatur bahwa segera setelah akta dibacakan, akta tersebut ditandatangani oleh setiap penghadap, saksi, dan notaris, kecuali apabila ada penghadap yang tidak dapat membubuhkan tandatangan dengan menyebutkan alasannya yangdinyatakan secara tegas dalam akta. Akta dalam bahasa asing ditandatangani oleh penghadap, notaris, saksi, dan penerjemah resmi.
Pembacaan, penerjemahan atau penjelasan, dan penandatanganan akta tersebut dinyatakan secara tegas pada akhir akta;

e. Notaris melanggar Pasal 48 UUJN, yang menyatakan bahwa isi akta dilarang untuk diubah dengan cara diganti, ditambah, dicoret, disisipkan, dihapus, dan/atau ditulis tindih. Perubahan isi akta berupa diganti, ditambah, dicoret, dan disisipkan dapat dilakukan dan sah jika perubahan tersebut diparaf atau diberi tanda pengesahan lain oleh penghadap, saksi, dan notaris;

f. Notaris melanggar Pasal 49 UUJN, yang mengatur bahwa setiap perubahan atas akta dibuat di sisi kiri akta. Apabila suatu perubahan tidak dapat dibuat di sisi kiri akta, maka perubahan tersebut dibuat pada akhir akta, sebelum penutup akta, dengan menunjuk bagian yang diubah atau dengan menyisipkan lembar tambahan. Perubahan yang dilakukan tanpa menunjuk bagian yang diubah, mengakibatkan perubahan tersebut batal;

g. Notaris melanggar Pasal 50 UUJN, yang menegaskan bahwa jika dalam akta perlu dilakukan pencoretan kata, huruf, atau angka, maka pencoretan dilakukan sedemikian rupa sehingga tetap dapat dibaca sesuai dengan yang tercantum semula dan jumlah kata, huruf, atau angka yang dicoret, dinyatakan pada sisi akta.Pencoretan tersebut dinyatakan sah setelah diparaf atau diberi tanda pengesahan lain oleh penghadap, saksi, dan notaris. Apabila terjadi perubahan lain terhadap pencoretan, maka perubahan itu 
dilakukan pada sisi akta. Pada penutup setiap akta dinyatakan tentang ada atau tidak adanya perubahan atas pencoretan;

h. Notaris melanggar Pasal 51 UUJN, yang menyatakan bahwa notaris berwenang untuk membetulkan kesalahan tulis dan/atau kesalahan ketik yang terdapat pada minuta akta yang telah ditandatangani.Pembentulan tersebut dilakukan di hadapan penghadap, saksi, dan notaris yang dituangkan dalam berita acara dan memberikan catatan tentang hal tersebut pada minuta akta asli dengan menyebutkan tanggal dan nomor akta berita acara pembetulan. Salinan berita acara tersebut, wajib disampaikan kepada para pihak; dan

i. Notaris melanggar Pasal 52 UUJN, yang menyatakan bahwa notaris tidak diperkenankan membuat akta untuk diri sendiri, isteri/suami, atau orang lain yang mempunyai hubungan kekeluargaan dengan notaris, baik karena perkawinan maupun hubungan darah dalam garis keturunan lurus ke bawah dan/atau ke atas tanpa pembatasan derajat, serta dalam garis ke samping sampai derajat ketiga, serta menjadi pihak untuk diri sendiri maupun dalam suatu kedudukan ataupun dengan perantaraan kuasa. Ketentuan ini tidak berlaku, apabila orang-orang yang disebut sebelumnya, kecuali notaris sendiri, menjadi penghadap dalam penjualan di muka umum, sepanjang penjualan itu dapat dilakukan dihadapan notaris, persewaan umum, atau pemborongan umum, atau menjadi anggota rapat yang risalahnya dibuat olehnotaris.

Habib Adjie, menyatakan bahwa sanksi terhadap notaris diatur pada akhir UUJN, yaitu pada Pasal 84 dan 85 UUJN, ada dua macam yaitu: ${ }^{23}$

a. Sanksi Perdata

Sanksi ini berupa penggantian biaya, ganti rugi atau bunga dapat dituntut terhadap Notaris harus didasarkan pada suatu hubungan hukum antara Notaris dengan Para Pihak yang menghadap Notaris, jika ada pihak yang merasa dirugikan sebagai akibat langsung dari suatu Akta Notaris, maka yang bersangkutan dapat menuntut secara perdata terhadap Notaris, dengan demikian tuntutan penggantian biaya, ganti rugi dan bunga terhadap Notaris tidak berdasarkan atas penilaian atau kedudukan suatu alat bukti yang berubah karena melanggar Pasal 84 UUJN, tapi hanya dapat didasarkan pada hubungan hukum yang ada atau yang terjadi antara Notaris dengan para penghadap;

b. Sanksi Administratif

Sanksi ini berupa:

1) Teguran Lisan

2) Terguran Tertulis

3) Pemberhentian Sementara

4) Pemberhentian dengan hormat

5) Pemberhentian tidak hormat

Dalam Pasal 84 UUJN ditentukan ada 2 (dua) jenis sanksi perdata, jika

23 Habib Adjie, Sanksi Perdata dan Administratif terhadap Notaris sebagai Pejabat Publik, Refika Aditama, Bandung, 2009. hlm. 91. 
notaris melakukan tindakan pelanggaran terhadap pasal-pasal tertentu dan juga sanksi yang sama jenisnya tersebar dalam pasal-pasal yang lainnya yaitu:

a. Akta notaris yang mempunyai kekuatan pembuktian sebagai akta di bawah tangan; dan

b. Akta notaris menjadi batal demi hukum;

Akibat dari akta notaris yang seperti itu, maka dapat menjadi alasan bagi pihak yang menderita kerugian untuk menuntut penggantian biaya, ganti rugi, dan bunga kepada notaris.

Untuk menentukan akta notaris yang mempunyai kekuatan pembuktian sebagai akta di bawah tangan dapat dilihat dan ditentukan dari:

a. Isi (dalam) pasal-pasal tertentu yang menegaskan secara langsung jika notaris melakukan pelanggaran, maka akta yang bersangkutan termasuk akta yang mempunyai kekuatan pembuktian sebagai akta di bawah tangan.

b. Jika tidak disebutkan dengan tegas dalam pasal yang bersangkutan sebagai akta yang mempunyai kekuatan pembuktian sebagai akta di bawah tangan, maka pasal lainnya yang dikategorikan melanggar menurut Pasal 84 UUJN, termasuk ke dalam akta batal demi hukum.

Dengan demikian dapat disimpulkan bahwa akta notaris yang mempunyai kekuatan pembuktian sebagai akta di bawah tangan, jika disebutkan dengan tegas dalam pasal yang bersangkutan, dan yang tidak disebutkan dengan tegas dalam pasal yang bersangkutan, termasuk sebagai akta menjadi batal demi hukum.
Batasan akta notaris yang mempunyai kekuatan pembuktian di bawah tangan sebagaimana tertuang di dalam Pasal 1869 KUH Perdata, dapat terjadi jika tidak memenuhi ketentuan karena:

a. tidak berwenang pejabat umum yang bersangkutan ; atau

b. tidak mampunya pejabat umum yang bersangkutan ; atau

c. cacat dalam bentuknya.

Meskipun demikian, akta seperti itu mempunyai kekuatan pembuktian sebagai akta dibawah tangan jika akta tersebut ditandatangani oleh para pihak.

Sanksi administratif, berupa teguran lisan, teguran tertulis, pemberhentian sementara, pemberhentian dengan hormat, dan pemberhentian tidak hormat tersebut berlaku secara berjenjang mulai dari teguran lisan sampai dengan pemberhentian tidak hormat, yaitu apabila notaris melanggar ketentuan pasal-pasal sebagaimana tercantum di dalam Pasal 85 UUJN.

Notaris dapat saja lepas dari tanggung jawab dan tanggung gugat hukum akibat akta yang dibuatnya cacat, sepanjang cacat hukum tersebut disebabkan oleh kesalahan pihak lain, atau keterangan atau bukti surat yang disampaikan oleh klien. Mengenal bentuk-bentuk penyebab cacat hukum yang bukan kesalahan notaris, misalnya adanya identitas aspal atau asli tapi palsu, seperti Kartu Tanda Penduduk, Kartu Keluarga, Paspor, Surat Keterangan Ahliwaris, Sertifikat, Perjanjian, Surat Keputusan, BPKB, Surat nikah, akta kelahiran dan lain-lain. Dokumen tersebut pada umumnya menjadi acuan notaris dalam pelayanan kepada masyarakat sebagai pejabat umum yang ditugasi 
mewakili negara dalam pembuatan akta autentik. $^{24}$

Permasalahannya bagaimana apabila dokumen-dokumen yang notabene merupakan produk hukum institusi negara dapat dengan mudah dipalsukan. Jelas hal ini sangat merugikan banyak pihak, termasuk profesi jabatan notaris. Semakin mudah dokumen dipalsukan berarti semakin besar kemungkinan notaris terseret kasus hukum, karena notaris hanya mendasarkan pembuatan akta pada kebenaran dokumen saja atau kebenaran formal, sedangkan kebenaran material berada pada para pihak dan produk hukum yang dibawa menghadap kepada notaris. Apabila keterangan yang disampaikan kepada notaris palsu atau dokumen yang diberikan kepada notaris palsu, maka akta dan pengikatan yang dibuat dihadapan notaris tidak berarti palsu. Apa yang disampaikan kepada notaris itu mengandung kebenaran, sedangkan fakta kebohongan yang disampaikan oleh penghadap bukan kewenangan dan bukan tanggungjawab notaris, karena akta notaris tidak menjamin bahwa pihakpihak berkata benar, tetapi yang dijamin oleh akta notaris adalah pihak-pihak benar berkata seperti yang termuat di dalam akta perjanjian mereka, sehingga apabila terjadi masalah dalam aspek materialnya seharusnya dilakukan penyidikan terlebih dahulu terhadap para pihak yang sengaja memberikan dokumen palsu kepada notaris, dan bukan sebaliknya notarisyang diperrsalahkan. Bahkan dalam kenyataannya proses hukumnya tidak hanya berhenti pada tahapan tersebut, notaris umumnya juga ikut dituduh berkolusi dengan para penghadap untuk menerbitkan akta notaris palsu.

Sebagaimana diketahui bahwa aspek material suatu akta notaris adalah kepastian tentang materi suatu akta, yaitu apa yang dituangkan dalam akta merupakan pembuktian yang sah terhadap pihak-pihak yang membuat akta atau pihak yang mendapat hak dan berlaku untuk umum. Keterangan atau pernyataan yang dimuat dalam akta pejabat atau keterangan para pihak yang diberikan atau disampaikan dihadapan notaris harus memiliki unsur kebenaran terhadap apa yang tercantum dalam akta.Jika keterangan/pernyataan para penghadap tersebut tidak benar, maka hal tersebut merupakan tanggung jawab para pihak itu sendiri. Dengan demikian, isi akta notaris mempunyai kepastian sebagai alat bukti yang sah untuk atau di antara para pihak, para ahli waris, dan para penerima hak.

Keterangan atau pernyataan para pihak yang disampaikan di hadapan notaris merupakan bahan dasar bagi notaris untuk membuatkan akta sesuai keinginan para pihak yang menghadap notaris. Tanpa adanya keterangan atau pernyataan dan keinginan para pihak, tidak mungkin notaris membuatkan akta. Apabila ada keterangan atau pernyataan yang diduga palsu yang dimasukkan ke dalam akta notaris, hal tersebut tidak menyebabkan akta tersebut palsu. Sebagai contoh, notaris memasukkan keterangan ke dalam akta notaris berdasarkan surat

$24 \quad$ Sjaifurrachman dan Habib Adjie, Aspek Pertanggungjawaban Notaris dalam Pembuatan Akta, Mandar Maju, Bandung, 2011, hlm. 26. 
identitas palsu (misalnya KTP palsu), tidak berarti notaris memasukkan keterangan palsu ke dalam akta notaris, sebagaimana dimaksud dalam Pasal 264 ayat (1) dan Pasal 266 ayat (1) KUHP. Secara material, kepalsuan atas hal tersebut merupakan tanggung jawab para pihak yang bersangkutan, kecuali jika notaris mengetahui kepalsuan tersebut.

Persoalannya adalah, bagaimana kedudukan akta notaris yang didasarkan pada keterangan atau pernyataan palsu tersebut ? Menurut Habib Adjie, penjatuhan pidana terhadap notaris, tidak serta merta menyebabkan akta yang dibuat menjadi batal demi hukum. Suatu hal yang tidak tepat secara hukum adalah apabila ada putusan pengadilan pidana dengan amar putusan membatalkan akta notaris, dengan alasan bahwa notaris terbukti melakukan suatu tindak pidana pemalsuan. Dengan demikian, hal yang harus dilakukan oleh pihak-pihak yang akan menempatkan notaris sebagai terpidana, atas akta yang dibuat oleh atau di hadapan notaris yang bersangkutan adalah, mengajukan gugatan secara perdata untuk meminta pembatalan akta tersebut. $^{25}$

Berdasarkan uraian di atas, diketahui bahwa terhadap akta notaris yang didasarkan pada keterangan palsu, tidak dengan sendirinya mengakibatkan akta tersebut menjadi batal demi hukum. Para pihak yang dirugikan dengan keberadaan akta seperti itu harus mengajukan gugatan perdata ke pengadilan untuk membatalkan akta tersebut. Akta tersebut akan batal apabila telah diputuskan oleh pengadilan dan putusan tersebut merupakan putusan yang memiliki kekuatan hukum yang tetap.

\section{Prospek Pengaturan Pertanggung- jawaban Pidana Notaris dalam UU Jabatan Notaris yang Akan Datang}

UU Nomor 30 Tahun 2004 tentang Jabatan Notaris tidak mengatur secara khusus tentang tindak pidana yang dilakukan notaris atau tindak pidana yang berkaitan dengan jabatan notaris. Undangundang tersebut telah diubah dengan UU Nomor 2 Tahun 2014 tentang Perubahan atas UU Nomor 30 Tahun 2004 tentang Jabatan Notaris. Dalam UU Nomor 2 Tahun 2014 juga tidak ada ketentuan yang mengatur tindak pidana yang dilakukan notaris atau tindak pidana yang berkaitan dengan jabatan notaris. Hal ini berarti, terhadap notaris yang melakukan tindak pidana yang terkait dengan jabatannya, berlaku ketentuan KUHP.

Pembentuk undang-undang mungkin belum merasa perlu untuk mengatur secara khusus tindak pidana yang dilakukan notaris terkait dengan jabatannya. Apabila dibandingkan dengan profesi lain yang diatur dalam undang-undang, seperti dokter, dan lain-lain, sudah ada pengaturan tentang tindak pidana yang terkait dengan profesinya. Menurut penulis, seharusnya dalam UUJN juga diatur tindak pidana yang dilakukan notaris terkait dengan profesinya karena notaris merupakan profesi yang penting.

Terkait dengan profesinya, notaris bisa saja melakukan tindak pidana, khususnya tindak pidana pemalsuan terhadap akta relaas atau akta pejabat

$25 \quad$ Ibid., hlm. 29. 
yaitu akta yang dibuat oleh (door enn) notaris berdasarkan pengamatan yang dilakukan notaris tersebut. Apabila seorang notaris melakukan tindak pidana pemalsuan dalam konteks tugasnya, maka notaris tersebut dapat diminta pertanggungjawaban pidana. Dalam hal ini, bisa terjadi bahwa notaris secara sengaja membuat akta relaas untuk dijadikan sebagai sarana melakukan tindak pidana yang diketahuinya sebagai tindakan yang melanggar hukum.

Perlunya pengaturan secara khusus tindak pidana yang terkait dengan jabatan notaris dalam UUJN, didasarkan pada fakta bahwa sering terjadi perbedaan penafsiran antara notaris dengan aparat penegak hukum. Oleh sebab itu, UUJN harus dijadikan sebagai pedoman dalam menentukan tindak pidana yang terkait dengan jabatan notaris. Batasan tindak pidana yang dilakukan notaris harus diukur berdasarkan UUJN, artinya perbuatan yang dilakukan oleh notaris melanggar ketentuan-ketentuan tertentu dalam UUJN. Hal ini penting karena ada kemungkinan bahwa menurut UUJN, akta yang dibuat notaris telah sesuai dengan ketentuan UUJN, sementara menurut aparat penegak hukum (polisi, jaksa, dan hakim), perbuatan tersebut merupakan suatu tindak pidana.

Dengan demikian, pertanggungjawaban pidana terhadap notaris dapat dilakukan dengan batasan: ${ }^{26}$

a. Ada tindakan hukum dari notaris terhadap aspek lahiriah, formal, dan material akta yang sengaja, penuh kesadaran dan keinsyafan serta direncanakan, bahwa akta yang dibuat oleh atau dihadapan notaris bersamasama (sepakat)para penghadap dijadikan dasar untuk melakukan suatu tindak pidana;

b. Ada tindakan hukum dari notaris dalam membuat akta oleh atau di hadapan notaris yang jika diukur berdasarkan UUJN, tidak sesuai dengan UUJN; dan

c. Tindakan notaris tersebut juga tidak sesuai menurut instansi yang berwenang untuk menilai suatu tindakan seorang notaris,dalam hal ini Majelis Pengawas Notaris.

Perlunya pengaturan pertanggungjawaban pidana notaris dalam UUJN, juga didasarkan pada pertimbangan bahwa penjatuhan sanksi pidana terhadap notaris dapat dilakukan sepanjang batasanbatasan sebagaimana dikemukakan di atas, memenuhi rumusan pelanggaran dalam UUJN, dan tentu saja KUHP sebagai lex generalis. Jika tindakan notaris memenuhi rumusan suatu tindak pidana, tetapi menurut UUJN bukan merupakan suatu pelanggaran, maka notaris yang bersangkutan tidak dapat diminta pertanggungjawaban pidana, karena ukuran untuk menilai sebuah akta notaris harus didasarkan pada UUJN.

Menurutpenulis, pertanggungjawaban pidana terhadap notaris terkait dengan akta notaris yang dihasilkannya, yang selama ini hanya didasarkan pada KUHP, perlu ditata kembali. Bagaimana pun, pertanggungjawaban pidana terhadap notaris terkait dengan akta yang dibuatnya sebagai produk pelaksanaan tugas jabatan atau kewenangan notaris, harus

$26 \quad$ Ibid., hlm. 30. 
memperhatikan aturan yang berkaitan dengan tata cara/prosedur dan syarat pembuatan akta, yaitu UUJN. Penggunaan KUHP sebagai aturan yang digunakan untuk mempidanakan notaris terkait dengan akta yang dibuatnya, menunjukkan telah terjadi kesalahpahaman atau penafsiran terhadap kedudukan notaris dan akta notaris sebagai alat bukti dalam hukum perdata.

Sebagaimana telah diuraikan tersebut di atas bahwa berdasarkan Pasal 1 ayat (1) dan Pasal 15 UUJN menyatakan bahwa notaris berwenang membuat akta autentik, yang selanjutya, notaris dalam menjalankan tugasnya perlu mendapatkan perlindungan dan jaminan demi tercapainya kepastian hukum, sehingga dalam menjalankan tugasnya notaris diatur dalam ketentuan UUJN, sehingga UUJN merupakan lex specialis dari KUHP, dan bentuk hubungan notaris dengan para penghadap harus dikaitkan dengan Pasal 1869 KUHPerdata. Bahkan seringkali apabila notaris terlibat dalam suatu tindakan hukum yang mengakibatkan notaris diperiksa oleh aparat penegak hukum seperti polisi atau kejaksaan, mereka memperlakukan notaris layaknya seorang penjahat yang harus mempertanggungjawabkan perbuatannya.

Terkait dengan pembuatan akta yang dilakukan oleh notaris, UUJN memberi perlindungan hukum kepada notaris sebagaimana termuat dalam ketentuan Pasal 4 ayat (2) tentang sumpah/janji notaris yang berbunyi antara lain: “... bahwa saya akan merahasiakan isi akta dan keterangan yang diperoleh dalam pelaksanaan jabatan saya.... Lebih lanjut diatur dalam kententuan Pasal 16 ayat
(1) huruf e, yang berbunyi antara lain: “... Dalam menjalankan jabatannya, Notaris berkewajiban: e.merahasiakan segala sesuatu mengenai akta yang dibuatnya dan segala keterangan yang diperoleh guna pembuatan akta sesuai dengan sumpah/ janji jabatan, kecuali Undang-Undang menentukan lain...."

Dalam hal mencegah lebih banyak lagi keterlibatan notaris dalam permasalahan hukum baik perdata maupun pidana, untuk itu penegakkan hukum dalam hal ini meliputi pengawasan dan sanksi harus benar-benar ditegakkan, pengawasan merupakan langkah preventif untuk memaksakan kepatuhan dan penerapan sanksi merupakan langkah represif untuk memaksakan kepatuhan tersebut. Dalam menegakkan sanksi administratif terhadap notaris yang menjadi instrument pengawasan yaitu Majelis Pengawas yang mengambil langkah-langkah preventif, untuk melaksanakan kepatuhan agar sanksi-sanksi tersebut dapat dilaksanakan.

\section{PENUTUP}

1. Notaris tidak dapat dimintai pertanggungjawaban pidana terkait dengan pembuatan akta pihak (partijn akten) yang didasarkan pada keterangan palsu, dan tidak dapat memenuhi rumusan unsur tindak pidana pemalsuan dalam Pasal 266 ayat (1) juncto Pasal 55 ayat (1) KUHP. Akan tetapi notaris dapat dimintai pertanggungjawaban pidana terhadap akta relaas atau akta pejabat (ambtelijke akten) jika secara sengaja atau lalai notaris membuat akta palsu, sehingga merugikan pihak lain.

2. Terhadap akta notaris yang dibuat 
berdasarkan keterangan palsu tidak dengan sendirinya mengakibatkan akta tersebut menjadi batal demi hukum. Para pihak yang dirugikan dengan keberadaan akta seperti itu harus mengajukan gugatan perdata ke pengadilan untuk membatalkan akta tersebut. Akta tersebut akan batal apabila telah diputuskan oleh pengadilan dan putusan tersebut merupakan putusan yang memiliki kekuatan hukum yang tetap; dan

3. Pertanggungjawaban pidana notaris perlu diatur dalam UU Jabatan Notaris secara tersendiri. Hal ini didasarkan pada pertimbangan berikut:

a. Adanya fakta bahwa sering terjadi perbedaan penafsiran antara notaris dengan aparat penegak hukum.

b. Penjatuhan sanksi pidana terhadap notaris dapat dilakukan sepanjang batasan-batasan pelanggaran yang dilakukan notaris memenuhi rumusan pelanggaran dalam UUJN; dan

c. Pertanggungjawaban pidana terhadap notaris terkait dengan akta yang dibuatnya sebagai produk pelaksanaan tugas jabatan atau kewenangan notaris, harus memperhatikan aturan yang berkaitan dengan tata cara/ prosedur dan syarat pembuatan akta, yaitu UUJN.

\section{DAFTAR PUSTAKA}

Adam Chazawi, Pelajaran Hukum Pidana 1: Stelsel Pidana, Tindak Pidana, Teoriteori Pemidanaan \& Batas Berlakunya
Hukum Pidana, RajaGrafindo Persada, Jakarta, 2007.

Andi Hamzah, Asas-asas Hukum Pidana, Edisi Revisi, Rineka Cipta, Jakarta, 2008.

Anke Dwi Saputro, Jati Diri Notaris Indonesia Dulu, Sekarang, Dan Di Masa Datang, Gramedia Pustaka Utama, Jakarta.

Chairul Huda, Dari Tiada Pidana Tanpa Kesalahan Menuju kepada Tiada Pertanggungjawaban Pidana Tanpa Kesalahan, Cet. Keempat, Kencana Prenada Media Group, Jakarta, 2011.

Dwidja Priyatno, Kebijakan Legislasi Tentang Sistem Pertanggungjawaban Pidana Korporasi di Indonesia, CV. Utomo, Bandung, 2009.

Emma Nurita, Cyber Notary, Pemahaman Awal Dalam Konsep Pemikiran, Cet. Kesatu, Refika Aditama, Bandung, 2012.

Erdianto Effendi, Hukum Pidana Indonesia Suatu Pengantar, Cet. Kesatu, Refika Aditama, Bandung, 2011.

G.H.S. Lumban Tobing, Peraturan Jabatan Notaris, Erlangga, Jakarta, 1982.

Habib Adjie, Hukum Notaris Indonesia (Tafsir Tematik Terhadap UU No. 30 Tahun 2004 Tentang Jabatan Notaris), Cet. Pertama, Refika Aditama, Bandung, 2009. 
,Sanksi Perdata dan Administratif terhadap Notaris sebagai Pejabat Publik, Refika Aditama, Bandung, 2009.

Hadi Setia Tunggal, Peraturan Pelaksanaan Undang-Undang Jabatan Notaris Dilengkapi Putusan Mahkamah Konstitusi \& AD, ART dan Kode Etik Notaris, Harvarindo, Jakarta, 2006.

Joko P. Subagyo, Metode Penelitian Dalam

Teori dan Praktek, Rineka Cipta, Jakarta, 1997.

Kelsen, Hans, General Theory Of Law and State, Teori Umum Hukum Dan Negara, Dasar-Dasar Ilmu Hukum Normatif Sebagai Ilmu Hukum Deskriptif Empirik, Alih Bahasa oleh Soemardi, BEE Media Indonesia, Jakarta, 2007.

Komar Andasasmita, Notaris Selayang Pandang, Cet. 2, Alumni, Bandung, 1983.

Komariah E. Supardjaja, Ajaran Melawan Hukum Materiil dalam Hukum Pidana Indonesia; Studi Kasus tentang Penerapan dan Perkembangannya dalam Yurisprudensi, Alumni, Bandung, 2002.

Krisna Harahap, Konstitusi Republik Indonesia Menuju Perubahan ke-5, Grafiti Budi Utami, Bandung, 2009.

Lexy J. Moleong, Metodologi Penelitian Kuantitatif, Remaja Rosda Karya, Bandung, 2000.
Liliana Tedjosaputro, Etika Profesi dan Profesi Hukum, Aneka Ilmu, Semarang, 2003.

Mariam Darus Badrulzaman, dkk., Kompilasi Hukum Perikatan, Citra Aditya Bakti, Bandung, 2001.

Moeljatno, Perbuatan Pidana dan Pertanggungjawaban dalam Hukum Pidana, Bina Aksara, Jakarta, 1985. ,Asas-Asas Hukum Pidana, Edisi Revisi, Rineka Cipta, Jakarta, 2008.

Muladi dan Dwidja Priyatno, Pertanggungjawaban Pidana Korporasi, Edisi Revisi, Kencana Prenada Media Group, Jakarta, 2010.

P.A.F. Lamintang, Delik-delik Khusus (Kejahatan-kejahatan Membahayakan Kepercayaan Umum Terhadap Suratsurat, Alat-alat Pembayaran, Alat-alat Bukti dan Peradilan), Mandar Maju, Bandung, 1991. ,dan C.Djisman Samosir, Delik-delik Khusus (Kejahatan yang ditujukan terhadap Hak Milik dan Lain-lain Hak Yang Timbul Dari Hak Milik), Aristo, Bandung, 1981.

Paulus Effendi Lotulung, Perlindungan Hukum Bagi Notaris Selaku Pejabat Umum Dalam Menjalankan Tugasnya, Edisi April, Media Notariat, Ikatan Notaris Indonesia, 2002. 
Pengurus Pusat Ikatan Notaris Indonesia, Jati Diri Notaris Indonesia, Gramedia Pustaka Utama, Jakarta, 2008.

Ronny Hanitjio Soemitro, Metodologi Penelitian Hukum dan Jurimetri, Cet. Keempat, Ghalia Indonesia, Jakarta, 1990.

R. Soegondo Notodisoerjo, Hukum Notariat di Indonesia, Suatu Penjelasan, Rajawali, Jakarta, 1982.

Sjaifurrachman dan Habib Adjie, Aspek Pertanggungjawaban Notaris dalam Pembuatan Akta, Mandar Maju, Bandung, 2011.

Sudarto, Hukum Pidana 1, Badan Penyediaan Bahan Kuliah Fakultas Universitas Diponegoro, Semarang, 1987/1988.

Kapita Selekta Hukum Pidana, Cet. Keempat, Alumni, Bandung, 2010

Sudikno Mertokusumo, Hukum Acara Perdata Indonesia, Liberty, Yogyakarta, 1998.

Teguh Prasetyo, Hukum Pidana, Edisi Revisi, RajaGrafindo Persada, Jakarta, 2012.

\section{Peraturan Perundang-undangan:}

Undang-Undang dasar 1945.

KUHP (Kitab Undang-Undang Hukum Pidana), terjemahan Moeljatno, Cet. Ke-19, Bumi Aksara, Jakarta, 1996.
Kitab Undang-Undang Hukum Perdata, terjemahan R. Subekti dan R. Tjitrosudibio, Cet. Ke-28 (Edisi Revisi), Pradnya Paramita, Jakarta, 1996.

Undang-Undang Nomor 30 Tahun 2004 tentang Jabatan Notaris jo. UU Nomor 2 Tahun 2014 tentang Perubahan atas UU Nomor 30 Tahun 2004 tentang Jabatan Notaris. 